Ernest Kuczyński

Łódź

\title{
MIĘDZY PAMIĘCIĄ A ZAPOMNIENIEM RECEPCJA I WIZERUNEK JÜRGENA FUCHSA W XXI WIEKU
}

Eigentlich wollte ich nur Gedichte schreiben, über die Liebe, über die Natur. Anderes, wichtigeres drängte sich vor ${ }^{1}$

Jürgen Fuchs

Milan Kundera pisząc swoją powieść „Księga śmiechu i zapomnienia” zamieścił w niej stwierdzenie, iż „Walka człowieka z władzą jest walką pamięci z zapomnieniem" ${ }^{\prime 2}$. W ten oto sposób czesko-francuskiemu autorowi udało się bardzo trafnie zdefiniować zarówno postawę życiową, jak i program literacki Jürgena Fuchsa (1950-1999) - pochodzącego z NRD pisarza, publicysty, eseisty, działacza na rzecz praw obywatelskich oraz psychologa, uważanego do momentu upadku muru za jednego z najważniejszych twórców żyjących na przymusowej emigracji w RFN.

Jürgen Fuchs - podobnie jak Kundera - został z powodów politycznych pozbawiony obywatelstwa i musiał opuścić ojczyznę, czego bezpośrednią przyczyną był trwający od dłuższego czasu konflikt z władzami państwowymi. U jego podłoża leżała twórczość literacka autora, który w czasach swojej spędzonej w NRD młodości opublikował drukiem kilkanaście utworów lirycznych i prozatorskich, lecz ich treść oraz wydźwięk wystarczyły w zupełności, by popaść w niełaskę partii SED (niem. Sozialistische Einheitspartei Deutschlands) i Ministerstwa Bezpieczeństwa Państwowego (niem. Ministerium für Staatssicherheit, w skrócie: MfS, potocznie: Stasi). Fuchs - jeszcze zanim został zmuszony do wyjazdu na

${ }^{1}$ Por. Scheer U., Gegen die Feigheit, „Rheinischer Merkur”, 07.05.2009.

2 Por. Kundera M., Księga śmiechu i zapomnienia, Warszawa 1993 (tłum. P. Godlewski, A. Jagodziński). 
zachód - dał się poznać jako osoba klarownie i otwarcie wyrażająca swoje myśli, tworząca według własnych, a nie narzuconych odgórnie schematów, sprzeciwiająca się dyktaturze, zniewoleniu i łamaniu praw człowieka, odważnie wskazująca na słabe punkty totalitarnego państwa, które oprócz nazwy nic nie łączyło z demokracją.

Na zachodzie Fuchs uczynił z motta Kundery nieodłączny element swojej biografii, w pełni utożsamiał się z nim, chętnie przytaczał w swoich tekstach ${ }^{3}$, zwracając uwagę na fakt, by pamięć wygrywała z zapomnieniem i charakteryzowała przesłanie większości jego utworów literackich i publicystycznych. Z kolei pojęcie „walka” niemiecki pisarz upodobał sobie szczególnie, postrzegając je jako tworzenie zaangażowanej literatury, posiadającej jasno określony program estetyczny, zawierający się w słowach: „Einmischung", ,Aufrichtigkeit”, „Aufklärung" oraz „Erinnerung”. Fuchs realizował go poprzez opisywanie faktów, dokumentowanie otaczającej rzeczywistości, przeprowadzanie wiwisekcji dyktatury, przedstawianie mechanizmów totalitarnej przemocy, odrzucenie postulatu "grubej kreski", odtajnianie ukrytej w aktach prawdy, a tym samym sprzeciwianie się „potężnemu lobby pochlebców, sprawców i osób idących na ustępstwa"4.

Jako autor nazywany był „strażnikiem pamięci”, który „nie tolerował nietolerancji”, przerywał wygodne dla niektórych kręgów milczenie o niechlubnej przeszłości, pisał przeciwko zapomnieniu i ignorancji, nie chciał bowiem dopuścić, by poprzez udawaną amnezję czy obojętność kolejny raz w Niemczech zagościł system autorytarny. W swojej twórczości skłaniał się początkowo ku liryce, później zaś prozie i publicystyce, poruszał trudne tematy: walkę ze zniewoleniem w systemie totalitarnym, konfrontację z władzą państwową, próby zachowania własnej tożsamości, brak szeroko pojętej wolności, przypadki łamania praw obywatelskich, które ukazywał m.in. na przykładzie stosunków panujących w armii NRD, traumatycznych doświadczeń z pobytu w areszcie śledczym, a także psychologii operacyjnej oraz "cichego" terroru Stasi. Warto podkreślić, że problematyka utworów Fuchsa jest w zdecydowanej większości oparta na autopsyjnych przeżyciach, w dużej mierze dotyczy jego wieloletniej inwigilacji przez wschodnioniemiecką bezpiekę, która mogła zostać udokumentowana na podstawie zabezpieczonych w latach 1989/90 tajnych akt MfS. Jego publikacje prezentowały prawdziwy, jednakże dla pewnych kręgów (także

${ }^{3}$ Słowa Kundery były cytowane przez Jürgena Fuchsa w języku niemieckim: „Der Kampf des Menschen gegen die Macht ist der Kampf des Gedächtnisses gegen das Vergessen". Por. Fuchs J., Poesie und Zersetzung: Erste Vorlesung in der Reihe Literatur zur Beförderung der Humanität (hrsg. von E. Kratschmer/U. Zwiener), Jena 1993, s. 58.

${ }^{4}$ Kratschmer E., Versus Diktatur. Texte zu Jürgen Fuchs, Unterwellenborn 2001, s. 26 (tłum. własne). 
w zjednoczonej RFN) niewygodny zapis wydarzeń, co przez szereg lat powodowało, że zdania co do jego osoby oraz twórczości były i są wyraźnie podzielone, a on sam jest uważany za ,jednego z najbardziej nieznanych lecz bardzo cenionych autorów tej (RFN - przyp. E.K.) republiki" ${ }^{\prime 5}$.

Owa sprzeczność w ocenie Jürgena Fuchsa wydaje się być jedną z przyczyn jego obecnej, nie prezentującej się nazbyt okazale recepcji. Należy stwierdzić, iż na początku XXI wieku jest on postrzegany za pisarza niedocenianego i w pewnym stopniu zapomnianego, a jego nazwisko przywoływane jest głównie $\mathrm{w}$ kontekstach historycznych, politycznych czy społecznych, natomiast sporadycznie literackich. Mimo, że jego publikacje były tłumaczone na wiele języków ${ }^{6}$, to zmarły w 1999 roku autor wydaje się być rozpoznawany poza granicami Niemiec jedynie przez germanistów oraz osoby z byłych kręgów opozycyjnych, natomiast w samej RFN kojarzony jest głównie jako dysydent, osoba wspomagająca ruch pokojowy w NRD, walcząca o prawa człowieka i obywatela, zaś po przełomie w 1989 roku zaangażowana w walkę o udostępnienie akt bezpieki i prowadząca działalność badawczą w Urzędzie Pełnomocnika Federalnego ds. Akt Służby Bezpieczeństwa byłej NRD (BStU, Abteilung Bildung und Forschung ${ }^{7}$ ). W dniu dzisiejszym coraz rzadziej można natrafić na odwołania do jego prozy, liryki, eseistyki, sztuk teatralnych bądź słuchowisk, zaś najczęściej do tekstów publicystycznych, szczególnie tych dokumentujących działalność i przestępstwa Stasi, co dobitnie pokazuje, jak jednoznacznie odbierane jest dziś jego bogate dzieło.

Chcąc w pełni zrozumieć literacką działalność Jürgena Fuchsa, należy odnieść się do jego ciekawej, spajającej klamrą życie w dwóch państwach i systemach biografii. Urodził się on 19 grudnia 1950 roku w Reichenbach (Vogtland), dorastał w rodzinie robotniczej, już jako nastolatek krytycznie przypatrywał się poglądom rodziców, środowisku, szarej enerdowskiej rzeczywistości, która w pewnym stopniu go przytłaczała i zachęcała do ucieczki w wypełniony literaturą świat - tak oto formuje się świadomy

${ }^{5}$ Rathenow L., Jürgen Fuchs, „Der Literat. Zeitschrift für Literatur und Kunst”, Heft 12/1999, s. 19 (tłum. własne).

${ }^{6}$ Poza granicami Niemiec jego dzieła bądź pojedyncze, drobne teksty przetłumaczone zostały na dziewięć języków (angielski, czeski, duński, francuski, holenderski, koreański, polski, szwedzki, włoski) i opublikowane w dwunastu krajach: Anglii, Australii, Austrii, Czechach, Dani, Francji, Korei, Polsce, RPA, Szwajcarii, Szwecji, USA. Por. bibliografia autora: Fuchs J., Poesie und Zersetzung..., op. cit., s. 87-100.

${ }^{7}$ Skrót BStU pochodzi od nazwy: der Bundesbeauftragte für die Unterlagen des Staatssicherheitsdienstes der ehemaligen DDR, z kolei Abteilung Bildung und Forschung (BF) to jeden z czterech wydziałów urzędu, zajmujący się prowadzeniem badań naukowych i edukacją społeczeństwa. Por. Kuczyński E., Działalność Urzędu ds. Akt Służby Bezpieczeństwa byłej NRD (BStU). Historia i perspektywy, [w:] Kuczyński E., Tomczyk M. (red.), Niemcy, Austria, Szwajcaria. Wyzwania z przełomu XX/XXI w., Łódź 2012, s. 39-49. 
i wewnętrznie wolny obywatel, już za młodu dostrzegający sprzeczność między głoszonymi ideałami a zwykłą codziennością.

Niezmiernie ważny w biografii pisarza jest rok 1968, będący nie tylko momentem uzyskania pełnoletniości, lecz przede wszystkim katalizatorem przemian prowadzących do przebudzenia światopoglądowego - interwencja wojsk radzieckich $\mathrm{w}$ Pradze powoduje u stojącego u progu dorosłego życia i wychowanego w duchu socjalizmu młodego człowieka swoistą utratę orientacji i krytyczną rewizję własnych przekonań. Dla Jürgena Fuchsa istotnym następstwem „Praskiej Wiosny” jest decyzja o spisywaniu przemyśleń w postaci wierszy, zawierających krytyczne spostrzeżenia i ciche pytania. Te pierwsze próby literackie stanowią podwaliny dla rodzącego się protestu, tym bardziej, że młody twórca dostrzega w pisaniu misję, pozwalającą mu na swobodne wyrażenie się, przerwanie milczenia i ucieczkę od przesiąkniętej dyktaturą codzienności.

Rok 1969 przynosi nie tylko świadectwo maturalne, lecz także powołanie do wojska. Fuchs, by ziścić marzenie o podjęcie studiów na uniwersytecie, odbywa półtoraroczną służbę w Narodowej Armii Ludowej (Nationale Volksarmee, w skrócie: NVA). Dla wkraczającego w dorosłe życie poborowego okres ten jest traumatycznym przeżyciem, które utwierdzi go w przekonaniu, że rejestrując każdy detal będzie mógł później opisać koszarową rzeczywistość i stworzyć prozę opisującą tabuizowane w NRD oblicze „maszynerii wojennej”.

Zmiana na stanowisku I sekretarza Niemieckiej Socjalistycznej Partii Jedności (SED) w 1971 roku przynosi dla obywateli NRD krótkotrwałą liberalizację polityki kulturalnej - Jürgen Fuchs otrzymuje pozwolenie na podjęcie studiów psychologicznych, które okażą się przełomowym okresem w jego biografii. Studiując ma nie tylko bezpośredni kontakt z uwolnioną częściowo od narzuconych rygorów i krytyczną literaturą (m.in. H. Novak, U. Plenzdorfa, R. Kunze, S. Heyma, W. Biermanna), lecz także możliwość zaobserwowania wszechwładności aparatu władzy, obecnego również w systemie szkolnictwa wyższego - wielu kolegów z roku okazuje się szkolonymi się na przyszłych psychologów studentami, którzy po uzyskaniu dyplomu będą zasilać szeregi służby bezpieczeństwa i pracować dla MfS jako eksperci m.in. w dziedzinie psychologii operacyjnej. To właśnie na uniwersytecie w Jenie, mieście znanym ze swojego opozycyjno-dywersyjnego potencjału ${ }^{8}$, krystalizuje się światopogląd Fuchsa, któ-

${ }^{8}$ Jena to jedno $\mathrm{z}$ nielicznych $\mathrm{w}$ NRD miast przejawiających wzmożone działania opozycyjne, które w licznych przypadkach inicjowane były w kręgach studenckich. Warto wspomnieć, iż działały tu m.in.: grupa skupiona wokół profesora filozofii - Hansa Leiseganga (koniec lat 40. XX w.), a w późniejszym czasie (1973-1975) „Arbeitskreis Literatur und Lyrik", zrzeszający wiele krytycznie nastawionych do otaczającej rzeczywistości młodych osób, w tym kolegów i przyjaciół Jürgena Fuchsa (m.in. L. Rathenow, B. Mar- 
ry w swoich lirycznych i prozatorskie utworach prezentuje obraz życia W "zdeformowanej rzeczywistości" ${ }^{\prime}$ NRD, opisując nie tylko własne doświadczenia, lecz także prawdziwy wizerunek dyktatury, struktur państwowych czy mechanizmów władzy.

Nie chcąc $\mathrm{z}$ racji swojej działalności literackiej popaść $\mathrm{w}$ konflikt z władzami uczelni oraz Stasi, a tym samym przedwcześnie zamknąć sobie drogi dokończenia studiów, jest on zmuszony balansować między pokusą otwartego wypowiedzenia myśli, a zawoalowanym przekazem, który w wielu miejscach zawiera znaczny potencjał wybuchowy. Jego misja pisarska - zawierająca się w słowach "Sagen was ist" - pozwala zdobyć uznanie w kręgach literackich, lecz uniemożliwia publikację większości napisanych utworów ${ }^{10}$, które przypadają do gustu nie tylko osobom z najbliższego otoczenia, lecz także uznanym w NRD autorom, m.in.: W. Biermannowi, R. Havemannowi, R. Kunze, G. Wolfowi czy G. Kunertowi. Owo wsparcie jest dla Jürgena Fuchsa ważnym czynnikiem w jego rozwoju, motywuje do podjęcia ryzyka oraz pokazania szerszej publiczności własnej samoświadomości i twórczości.

Na skutki takiej postawy nie trzeba było długo czekać - rok 1975 przynosi eskalację konfliktu $\mathrm{z}$ aparatem państwowym. Jürgen Fuchs zostaje wykluczony z SED oraz FDJ, a tuż przed obroną ocenionej na „bardzo dobry” pracy magisterskiej skreślony z listy studentów i relegowany z uczelni. Ponadto niedoszły psycholog zostaje obłożony zakazem publikacji i występowania, na każdym kroku jest inwigilowany przez funkcjonariuszy Stasi, która stosując liczne „środki dywersyjne” (niem. Zersetzungsmaßnahmen ${ }^{11}$ ) skutecznie uprzykrza życie młodego pisarza

kowsky, S. Reiprich, U. Scheer, T. Auerbach, W. Hinkeldey, D. Liebermann, R. Ellmenreich, R. Jahn). Por. Scheer U., Vision und Wirklichkeit. Die Opposition in Jena in den siebziger und achtziger Jahren, Berlin 1999; Fritsch W., Nöckel W., Vergebliche Hoffnung auf einen politischen Frühling - Opposition und Repression an der Universität Jena (1956-1968). Eine Dokumentation, Berlin 2006; Kaiser T., Mestrup H. (Hg.), Politische Verfolgung an der Friedrich-SchillerUniversität Jena von 1945 bis 1989. Wissenschaftliche Studien und persönliche Reflexionen zur Vergangenheitsklärung, Berlin 2012.

9 Zybura M. (red.), Pisarze niemieckojezzyczni XX w. Leksykon encyklopedyczny PWN, Warszawa 1996, s. 96.

${ }^{10}$ Do momentu aresztowania i wyjazdu na przymusową emigrację J. Fuchs opublikował w NRD kilkanaście wierszy, ukazały się one w następujących antologiach: Poesiealbum. Sonderheft Poetenseminar 1971 (red. H. Würtz), Berlin 1971; Offene Fenster. Schülergedichte (red. E. und M. Kratschmer), Bd. 3, Berlin 1972; Offene Fenster. Schülergedichte (red. E. und M. Kratschmer, H. Würtz), Bd. 4, Berlin 1973; Auswahl 74. Neue Lyrik - Neue Namen (red. B. Jentzsch u.a.), Berlin 1974; Treffpunkt Klub, Gera 4/1974.

11 Pojęcie to zostało po raz pierwszy użyte przez MfS w 1976 roku („,Richtlinie nr 1/76 zur Entwicklung und Bearbeitung Operativer Vorgänge") i oznaczało nową formę zwalczania szeroko pojętej opozycji wewnątrz NRD. Jej innowacyjność polegała na odejściu od stosowanych wcześniej przez Stasi metod (m.in. kryminalizowanie obywateli, groźby, zastraszanie, 
i jego rodziny. By odżegnać niebezpieczeństwo aresztowania, Fuchs wyjeżdża z Jeny i przenosi się do Grünheide pod Berliniem, gdzie znajduje schronienie w domu Roberta Havemanna. Owo zaproszenie okazuje się ratującym azylem, pozwalającym przyszłemu dysydentowi jeszcze przez kilka miesięcy cieszyć się wolnością. Jednakże na skutek dalszej „wrogiej działalności przeciwko państwu"12 Fuchs zostaje zatrzymany przez Stasi i na dziewięć miesięcy uwięziony w berlińskim areszcie MfS - Hohenschönhausen ${ }^{13}$. Na szczęście na zachodzie ukazuje się przygotowany na wypadek aresztowania jego literacki debiut "Gedächtnisprotokolle” (oddany do druku przez Wolfa Biermanna) ${ }^{14}$, który zwraca uwagę opinii publicznej na los pisarza. Dzięki inicjatywie "Schutzkomitee Freiheit und Sozialismus" ${ }^{\prime 15}$ oraz międzynarodowym protestom (m.in. prominentnych autorów: H. Bölla, F. Dürennmatta, H.M. Enzensbergera czy M. Frischa) dochodzi do uwolnienia pisarza, który wbrew własnej woli zostaje pozbawiony obywatelstwa NRD i wydalony z kraju.

przemoc fizyczna), a zwróceniu szczególnej uwagi na skierowanej przeciwko poszczególnym osobom bądź ugrupowaniom opozycyjnym psychologicznej manipulacji, mającej na celu ograniczenie lub zablokowanie „wrogo-negatywnych” działań przeciwko państwu. MfS chcąc zadbać o swój wizerunek przestawiła się częściowo na nową, niejawną technikę pracy, stosując m.in. następujące metody: publiczną dyskredytację, rozpowszechnianie kompromitujących materiałów, rozpuszczanie plotek, „aranżowanie niepowodzeń w życiu zawodowym i kontaktach społecznych, podkopywanie przekonań i budzenie wątpliwości w wymiarze osobistym", oddelegowywanie do odległych miejsc pracy, tworzenie licznych upozorowanych sytuacji w dniu codziennym i in. Por. m.in.: Gieseke J., Stasi. Historia 1945-1990, Kraków 2010, s. 206-207; Engelmann R., Florath B., Heidemeyer H., Münkel D., Polzin A., Süß W. (red.), Das MfS-Lexikon. Begriffe, Personen und Strukturen der Staatssicherheit der DDR, Berlin 2011, s. 352-353; Fuchs J., Unter Nutzung der Angst. Die "leise" Form des Terrors - Zersetzungsmaßnahmen des MfS, Berlin 1994 (BStU, seria „BF informiert", Heft 2/1994, ss. 40).

${ }^{12}$ Kodeks karny NRD określał zarzut ten mianem "staatsfeindliche Hetze” (§ 106 StGB der DDR) i dopuszczał wyznaczenie kary pozbawienia wolności od 1 roku do 5 lat, zaś w ciężkich przypadkach od 2 do 10 lat.

${ }^{13}$ Warto odnotować, iż bezpośrednią przyczyną aresztowania pisarza w dniu 19.11.1976 r. był nie tylko fakt okazania aktu solidarności W. Biermannowi i złożenie podpisu pod petycją przeciwko jego wypędzeniu, lecz ogólne zaostrzenie się sytuacji wokół J. Fuchsa, na które składały się przede wszystkim publikacja sześciu krótkich tekstów prozatorskich („Das Interesse”, "Die Wende”, „Die Vorladung”, „Die rote Fahne”, „1968”, „Für S.F.”) w zachodnioniemieckim tygodniku „Deutsches Allgemeines Sonntagsblatt” (z dn. 19.09.1976), a także wyemitowana w pierwszym programie niemieckiego radia (Deutschlandfunk) w dniu 11.11.1976 r. audycja "Literarisches Atelier", w której również zaprezentowane została krótka proza autora (teksty: „Der Auftakt”, „Das Fenster", „Das Kind”, „Der Schrei", „Der Frieden”, ,Die Verwandlung”, „Die Vorladung”, ,Der Unterricht”).

${ }^{14}$ Fuchs J., Gedächtnisprotokolle, Reinbek 1977.

${ }_{15}$ Por. Schwenger H., Das Schutzkomitee Freiheit und Sozialismus in Selbstzeugnissen, Dokumenten, Briefen und im Zerrspiegel der MfS-Akten. Berlin 1995. 
Przyjazd do Berlina Zachodniego rozpoczyna nowy etap w życiu Jürgena Fuchsa, który na zachodzie inicjuje swoją pisarską krucjatę - autor w pełni korzysta z możliwości swobodnego wyrażania myśli, dużo publikuje ${ }^{16}, \mathrm{w}$ pewien sposób redefiniuje swój program estetyczny, zakładający przede wszystkim „informowanie [...], autentyczność, literackość”, odrzucenie patosu, a ponadto „dokładne dokumentowanie doświadczeń $\mathrm{w}$ prozie i jasny, przejrzysty język w liryce"17. Fuchs postrzega literaturę jako drogę ukazywania prawdy przy pomocy środków sztuki, chce stawić czoła konfliktom, naświetlać problemy, precyzyjnie analizować mechanizmy ucisku, a nade wszystko ukazać na własnym przykładzie, że istnieje możliwość niedostosowania się, podjęcia walki i nie ulegania narzucanym normom czy schematom. Warto zauważyć, iż ów zrodzony w NRD nonkonformizm determinuje całą biografię Jürgena Fuchsa, nie ustaje wraz $\mathrm{z}$ upadkiem muru i ponownym zjednoczeniem, dochodzi do głosu $\mathrm{w}$ jego licznych tekstach, przede wszystkim prozatorskich oraz publicystycznych, gdzie w pełni realizuje swoje literackie credo: "Ich schweige nicht”.

W Berlinie Zachodnim Fuchs podejmuje zatrudnienie jako psycholog społeczny („Treffpunkt Waldstraße”), lecz cały czas pracuje jako wolny autor. Wśród jego publikacji pojawiają się dwa tomiki wierszy (,Tagesnotizen” i „Pappkameraden”18), ukazujące wyobcowanie w społeczno-politycznych realiach zachodu, trudności w dostosowaniu się do zastanej rzeczywistości, obcą topografię, niezrozumiałą codzienność, która ożywia wspomnienia i przywołuje biograficzne „odpryski”: znajome krajobrazy, miejsca oraz osoby. Jürgen Fuchs postrzega przesiedlenie do zachodniej części Niemiec nie jako „przeprowadzkę do innego miasta”, lecz „krok z jednego świata do drugiego", dlatego też w jego liryce pojawia się krytyczny dystans do RFN, wyobcowanie, tęsknota, rozrachunek z przeszłością, a także niezadowolenie z przymusowej emigracji, określanej mianem „[...] obczyzny mówiącej moim językiem"19.

Znawca wschodnioniemieckiej literatury - Wolfgang Emmerich, dostrzega u nie mogącego odnaleźć się w nowej sytuacji życiowej pisarza symptom charakterystyczny dla wielu krytycznych autorów w NRD,

${ }^{16}$ Wszystkie pozycje zwarte (tomiki wierszy, krótka proza) J. Fuchs mógł opublikować dopiero na emigracji w Niemczech Zachodnich. W latach 1977-1989 wydał on drukiem następujące pozycje: Gedächtnisprotokolle, Reinbek 1977; Vernehmungsprotokolle. November ,76 bis September ,77, Reinbek 1978; Tagesnotizen. Gedichte, Reinbek 1979; Pappkameraden. Gedichte, Reinbek 1981; Einmischung in eigene Angelegenheiten. Gegen Krieg und verlogenen Frieden, Reinbek 1984; Fassonschnitt, Reinbek 1984; Das Ende einer Feigheit, Reinbek 1988.

${ }^{17}$ Fix U., Widerständige Sprache in der Literatur der DDR am Beispiel Jürgen Fuchs, [w:] DDR-Literatur. Zwischen Anpassung und Widerspruch (hrsg. M. Hermann/H. Pietzsch), Jena 2011, s. 81, 83 (tłum. własne).

${ }_{18}$ Por. przypis 16.

19 Emmerich W., Kleine Literaturgeschichte der DDR, Leipzig 1996, s. 419 (tłum. własne). 
którzy „artykułują swój protest przeciwko [...] panującemu reżimowi, przez długi czas postrzegając wartości przez pryzmat utopijnego, 'prawdziwego' socjalizmu. Lecz potrzeba czasu, aby ludzie ci zrozumieli, że już Lenin (a nie dopiero Stalin) ze swoimi wyobrażeniami o rewolucji i brutalnym, pełnym przemocy 'oczyszczeniu' starego społeczeństwa należy do tych, na których nie należy się powoływać, lecz, wręcz przeciwnie, trzeba zwalczać" ${ }^{\prime 2}$.

Wolf Biermann chcąc określić postawę Jürgena Fuchsa użył niegdyś niezwykle trafnego sformułowania „ein unvermischtes DDR-Produkt”21. Słowa te w pełni definiują nie tylko przekonania, lecz także sposób postrzegania urodzonego w Turyngii autora, który zanim wstąpił na dysydencką ścieżkę przez długi czas podążał za utopijnym hasłem „socjalizm z ludzkim obliczem", wierzył w potencjał opartego na marksizmie-leninizmie systemu, angażował się jako pisarz, czytał dzieła klasyków i głoszone przez nich teorie, chciał bowiem zmienić ojczyznę „od środka”. Lecz by uświadomić sobie niedoskonałości socjalistycznego państwa oraz zmienić światopogląd, Fuchs potrzebuje czasu i szeregu doświadczeń - są nimi: „Praska Wiosna”, służba wojskowa, okres studiów, ograniczenia społeczne, separacja oraz wyrzucenie z kraju którego - podobnie jak jego przyjaciele R. Havemann i W. Biermann - postanowił nie opuszczać. Jednakże w NRD nie tolerowano podobnych jemu reformatorów, osadzano w więzieniu bądź usuwano jako „wrogo-negatywne elementy”, odbierając im przy tym obywatelstwo lub sprzedając sąsiadowi zza „, antyfaszystowskiego wału ochronnego".

W opinii Emmericha, Fuchs chyba najdłużej ze wszystkich pisarzy, którzy znaleźli się na emigracji w RFN, postrzegał się jako „wschodnio-zachodni autor na nieznanym lądzie”, bowiem „Silniej niż inni wciąż powraca do autobiograficznych, autentycznych tematów ze swojej spędzonej w NRD przeszłości"22. I rzeczywiście - Jürgen Fuchs także w powieściach („Fassonschnitt” i „Das Ende einer Feigheit”23) nawiązuje do czasów swojej przypadającej na lata 1969-1971 służby wojskowej w NVA, wyraziście opisując koszarową rzeczywistość, precyzyjnie oddając panujące $\mathrm{w}$ armii stosunki, protokółując przy tym własne przeżycia oraz poczynione obserwacje: wojskowy dryl, rozkazy, militaryzację dnia codziennego, posłuszeństwo, stosunek podwładności oficer-rekrut, a także kojarzące się z okresem narodowego socjalizmu flagi, chusty, apele i mundury. Decydując się na przedstawienie wątku armii z perspektywy rekruta oraz stu-

${ }^{20}$ Tenże, DDR-Literatur zwischen Anpassung und Widerspruch, [w:] DDR-Literatur..., op. cit., s. 50 (tłum. własne).

${ }^{21}$ Biermann W., Zwei Porträts, [w:] Fuchs J., Gedächtnisprotokolle..., op. cit., s. 7.

${ }^{22}$ Emmerich W., Kleine Literaturgeschichte..., op. cit., s. 424 (tłum. własne).

${ }^{23}$ Por. przypis 16 . 
denta odbywającego szkolenie wojskowe po odbyciu służby zasadniczej, pisarz ukazuje także moralne zagrożenie jednostki, która musi nie tylko oprzeć się własnym słabościom, poniżaniu czy szykanom, lecz także poradzić sobie z olbrzymim obciążeniem psychicznym.

W swoich zarówno lirycznych, jak i prozatorskich utworach Fuchs rezygnuje z zawiłej metaforyki i wyszukanej stylistyki, nazywając rzeczy po imieniu przedstawia stan faktyczny, odrzuca dwuznaczność na rzecz czytelnego przekazu, a wszystko to w celu dotarcia do czytelnika i uratowania od zapomnienia istotnych dla niego tematów. Tym samym staje się on jednym z pierwszych i najważniejszych dokumentarzystów NRD, pozostając nieczułym na "obietnice" nowego otoczenia i opierając się zawarciu przedwczesnej znajomości ze światem zachodu znacznie odstaje od kanonu literackiego lat 80., a tym samym kontynuuje swoją pisarską misję w duchu „produktywnego sprzeciwu”, wierząc, że „literatura jest w stanie coś osiągnąć i zmienić tam, gdzie istnieje kłamstwo, przymus i ucisk"24.

$\mathrm{Z}$ biegiem czasu Jürgen Fuchs coraz chętniej i częściej publikuje na łamach prasy, jego artykuły pojawiają się w wielu uznanych dziennikach i tygodnikach ogólnoniemieckich, tu bowiem dostrzega możliwość szybszego i skuteczniejszego dotarcia do czytelnika oraz wyrażenia swoich zapatrywań. Angażuje się w ruch na rzecz pokoju, walcząc o prawa człowieka współpracuje z „Amnesty International”, utrzymuje kontakty z członkami kręgów opozycyjnych z NRD, Czechosłowacji (,Karta 77”) oraz Polski („Solidarność"), sięga po tematy polityczne, łamie tabu opisując m.in. słabe punkty realnego socjalizmu, metody działania Stasi czy wykup więźniów, popadając jednocześnie w kolejny konflikt z aparatem wschodnioniemieckiej bezpieki.

MfS chcąc ukrócić „szkodzącą wizerunkowi NRD” publicystyczno-literacką działalność Fuchsa, wszczyna przeciwko niemu postępowanie przygotowawcze, wdraża w życie wymyślne i uciążliwe dla rodziny „środki dywersyjne”, a ponadto starannie inwigiluje środowisko autora. Stasi zamierzając unieszkodliwić „wroga państwowego” rozpracowuje go operacyjnie (w tzw. OV ${ }^{25}$ ), korzysta z usług licznych tajnych współpracowników, szkodzi jego wizerunkowi publicznemu, nie oszczędzając także

${ }^{24}$ Emmerich W., Kleine Literaturgeschichte..., op. cit., s. 298, 424 (tłum. własne).

${ }^{25}$ Pod pojęciem „Operativer Vorgang” (OV) należy rozumieć sprawę operacyjna, zakładaną w celu rozpoczęcia zarówno tajnego, jak i częściowo jawnego dochodzenia przeciwko pojedynczej osobie (bądź grupie osób), która z punktu widzenia MfS popełniła wykroczenie noszące znamię czynu przestępczego. OV wszczynano w celu wyjaśnienia zdarzeń określanych jako „negatywno-wroga działalność”, co należy rozumieć jako naruszenie obowiązujących w NRD norm politycznych. Por. m.in.: Engelmann R., Florath B., Heidemeyer H., Münkel D., Polzin A., Süß W. (red.), Das MfS-Lexikon. Begriffe, Personen und Strukturen der Staatssicherheit der DDR, Berlin 2011, s. 231-232. 
mieszkającej w Niemczech Wschodnich rodziny. Jednakże autor wydaje się ignorować ciche formy terroru Stasi i kontynuuje opozycyjną działalność: coraz bardziej angażuje się na rzecz ruchu pokojowego, wspiera rodzące się w NRD inicjatywy obywatelskie, prezentuje swoje doświadczenia i poglądy na zagranicznych konferencjach, co powoduje, że Stasi podejmuje zdecydowane kroki mające na celu dezorientację, rozpracowanie i unieszkodliwienie "bandy Fuchsa”, a przede wszystkim ukrócenie działalności jej przywódcy, który „,w opinii MfS uchodził na początku lat 80. (XX w. - przyp. E.K.) za jednego z najniebezpieczniejszych wrogów NRD w Berlinie Zachodnim" ${ }^{\prime 26}$. W obliczu faktu, iż metody bezpieki nie przynosiły zamierzonego skutku, szef MfS - Erich Mielke, podejmuje w maju 1982 roku decyzję o wydaniu ponownego nakazu aresztowania pisarza, który zostałby wykonany $\mathrm{w}$ momencie przekroczenia granicy NRD bądź wizyty w jednym z państw bloku socjalistycznego.

W tym kontekście warto zaznaczyć, iż Jürgen Fuchs jako autor niewygodny dla wschodnioniemieckiej bezpieki polaryzował także opinię publiczną i to zarówno przed rokiem 1989, jak również po upadku muru. Jego wieloletnia działalność i twórczość pozwoliły mu dorobić się nie tylko licznego grona zwolenników (popierali go m.in. R. Kunze, H. Böll, R. Havemann, R. Giordano, H. Müller), lecz również zagorzałych przeciwników, wypowiadających się z dezaprobatą o jego literaturze oraz upatrujących w jego osobie nie literata, a awanturnika, podżegacza, oszczercę, buntownika i fundamentalistę. Wspomniana polaryzacja to wynik zarówno pisarskiej, jak i obywatelskiej postawy Fuchsa, który świadomie decydował się na trudne tematy, trafiające w czułe punkty niemieckiej rzeczywistości, także tej pozjednoczeniowej.

Jednakże należy zwrócić uwagę na fakt, iż jego przydomki „Mahner”, „Stasi-Jäger", „Chronist der Zersetzung” czy „Protokollant des Unrecht”27 odzwierciedlają nie jego fanatyzm czy traumę, lecz również - o czym się jednak często zapomina - zaangażowanie $\mathrm{w}$ tzw. proces rozliczenia się z przeszłością, do którego należy m.in. przekazywanie niewygodnej prawdy, opisywanie doświadczeń, wskazywanie sprawców i ofiar dyktatury, wytykanie błędów czy ostrzeganie przed zagrożeniem. Oczywiście w ten nurt wpisuje się wielu twórców, także tych wywodzących się z NRD, ale

${ }^{26}$ Scheer U., Jürgen Fuchs. Ein literarischer Weg in die Opposition, Berlin 2007, s. 249. Warto odnotować, iż Stasi kilkakrotnie podejmowała próby (nieudanych) zamachów na życie pisarza, także już podczas jego pobytu w Berlinie Zachodnim. Z kolei już po upadku muru berlińskiego J. Fuchs otrzymywał anonimowe pogróżki, próbowano również manipulować przy układzie hamulcowym i oponach jego samochodu, jednakże nigdy nie udało się ustalić sprawców. Por. Scheer U., Jürgen Fuchs..., op. cit., s. 348-354.

${ }_{27}$ Kratschmer E., Erster Versuch einer Übersicht der Wirkung des literarischen Werkes von Jürgen Fuchs, [w:] "Gerbergasse 18”, Sonderausgabe zum Fuchs-Symposium „Einmischung in eigene Angelegenheiten", Jena 2001, s. 36. 
to właśnie Fuchs - pisarz znany ze swojej wiarygodności, doskonale obeznany z "czarną" psychologią Stasi, dysponujący ekspercką wiedzą - był postrzegany jako znawca tematu, który „z wyczuciem [...] uzmysławiał i w przejrzysty sposób przekazywał czytelnikom swoich książek, osobom biorącym udział w parlamentarnych przesłuchaniach, w licznych wykładach i rozmowach okrutne mechanizmy oraz wrogie człowiekowi cele dywersji i [...] środków operacyjnych"28. W 1991 roku autor określił owe „psychiczne spustoszenia”, spowodowane wieloletnimi aresztowaniami oraz niezwykle intensywną inwigilacją ze strony służby bezpieczeństwa mianem "Auschwitz in den Seelen", czym po raz kolejny wywołał falę krytyki ${ }^{29}$.

Trzeba jednak pamiętać, że problematyka Stasi nie była dla Jürgena Fuchsa jedynym punktem odniesienia, a na jego program literacki składało się wiele zagadnień $-\mathrm{w}$ dniu dzisiejszym częstokroć zapomina się o wszechstronności pisarza, który podążając za słowami swojego mentora z czasów młodości - Reinera Kunze, w pełni identyfikował się ze stwierdzeniem „Sztuka nie zna żadnych kompromisów”30. Jak wiadomo, twórczość Fuchsa nie znała kompromisu - cechował ją zrozumiały, wiernie oddający opisywaną sytuację język, ukryta na dalszym planie literackość, brak zbytecznych upiększeń, skromność w doborze środków stylistycznych, lecz posiadała za to jasne, choć nie dostrzegane przez wszystkich przesłanie autora: wolność jednostki, swoboda tworzenia oraz godność człowieka.

Tutaj dochodzimy - w mojej opinii - do kluczowego momentu recepcji i wizerunku pisarza, który na skutek niewłaściwego odbioru jego utworów, niedokładnej analizy twórczości oraz niedostatecznej znajomość biografii zaszufladkowany zostaje przez wielu odbiorców jako autor stricte polityczny, publicysta, kronikarz spisujący fakty i usiłujący tworzyć teksty spełniające literackie kryteria. Jednakże przypatrując się dokładniej całokształtowi kręgów tematycznych występujących w jego prozie, liryce i publicystyce, dochodzi się do wniosku, że jest on oceniany głównie poprzez pryzmat typowego dla niego nonkonformizmu, nieustępliwości, prawdomówności, a więc postaw, które przysparzają jednostce więcej wrogów niż przyjaciół. Badając recepcję tego intensywnego i oryginalnego autora nie wystarczy kierować się wyłącznie kryteriami literaturoznawczymi, trzeba także pamiętać, że żył on w dwóch skrajnych systemach: totalitaryzmie

${ }^{28}$ Cytat z przemówienia Christine Lieberknecht - przewodniczącej parlamentu kraju związkowego Turyngii. Por. "Gerbergasse 18”, Sonderausgabe..., op. cit., s. 6 (tłum. własne).

${ }^{29}$ Por. Serke J., "Die Opfer der Diktatur sitzen nicht in den Talk-Shows", "Die Welt", 4.11.1991; Martin M., Diese seltsame Anhänglichkeit, „Die Tageszeitung”, 28.04.1993.

${ }^{30}$ Jentzsch B., Kunert G., Rachowski U., Schädlich H.J. (u.a.), "Deutschunterricht", Sonderheft: Dissidenten? Texte und Dokumente zur DDR- „Exil"-Literatur, Heft 43, Berlin 1990, s. 489. 
i demokracji, że ów specyficzny kontekst historyczno-społeczny kładzie się cieniem zarówno na jego życiorysie, jak i twórczości, która wprawdzie w znacznej części przypada na okres przymusowej emigracji spędzonej w Berlinie Zachodnim, lecz światopogląd i decydujące o rozwoju jednostki doświadczenia ukształtowane zostały w państwie komunistycznym. Zatem, by przede wszystkim zrozumieć i prawidłowo zinterpretować literackie przesłanie Fuchsa należy postępować interdyscyplinarnie, odnieść się do jego spuścizny nie tylko w kontekście literatury, lecz także psychologii, historii, socjologii czy politologii. Owo kompleksowe ujęcie dzieła pisarza pozwala na odszukanie wielu istotnych powiązań, które w połączeniu z dokładną analizą wątków biograficznych ukazują pełniejszy obraz życia i twórczości tego zaangażowanego opozycjonisty.

W dniu dzisiejszym natrafić można na wiele informacji dotyczących Jürgena Fuchsa, które odnoszą się do opublikowanej na rok przed jego śmiercią powieści „Magdalena” ${ }^{\prime 31}$, postrzeganej za swoisty rozrachunek autora z dyktaturą NRD oraz zapisaną w aktach Stasi przeszłością. Jednakże należy pamiętać, że książka ta to ważny, lecz nie jedyny element jego spuścizny, tym bardziej, że miał to być pierwszy z trzech tomów planowanej trylogii, która na skutek przedwczesnej śmierci pisarza nie została ukończona. „Magdalena” to pozycja trudna w odbiorze i wielowarstwowa, mimo to przyniosła pisarzowi znaczny rozgłos, trafiła na listę bestsellerów, była szeroko komentowana w niemieckich mediach, rozpętała społeczną debatę, doczekała się ponad stu recenzji prasowych, natomiast swoją treścią i wydźwiękiem pokazała, jak skrajne mogą być reakcje wywołane literaturą Fuchsa.

Dla jednych jawi się on jako obsesyjny i nadgorliwy „sprawozdawca”, niewygodny przeciwnik $w$ walce o zapomnienie grzechów MfS, pewny siebie mąciwoda, w uporczywy sposób rozprawiający się z przeszłością, która w jego przypadku „,nie chciała przeminąć”. Z kolei zwolennicy Fuchsa doceniają nie tylko autentyczność tego przenikliwego, oczytanego i inteligentnego autora, przez lata precyzyjnie wskazującego, jak rodzi się przemoc, lecz także jego odwagę w podejmowaniu tematów, które ukazywały nagą prawdę o tym, co dzieje się „antyfaszystowskim” państwie, w tamtejszych „więzieniach, szpitalach dla umysłowo chorych, koszarach, szkołach" ${ }^{\prime 2}$. Po dziś dzień legenda pisarza odpokutowuje fakt, iż w żadnym momencie swojej

${ }^{31}$ Fuchs J., Magdalena. MfS, Memfisblues, Stasi, Die Firma, VEB Horch E Gauck - ein Roman, Reinbek 1998. Tytułowa „Magdalena” to odniesienie do mieszczącej się w dzielnicy Lichtenberg w Berlinie centrali MfS, położonej przy Magdalenenstraße, gdzie Erich Mielke stworzył swoje imperium. W dniu dzisiejszym znajduje się tam muzeum, które gromadzi, przechowuje, dokumentuje, opracowuje naukowo i udostępnia zwiedzającym materiały związane z systemem politycznym NRD. Por. www.stasi-museum.de

${ }^{32}$ Fuchs J., Hieke G., Dummgeschult? Ein Schüler und sein Lehrer, Berlin 1992, s. 5 (tłum. własne). 
kariery literackiej nie szedł na ustępstwa, mimo przeciwności pozostał szczery, wpisując się na stałe w określoną tematykę, która w pewnym sensie przyćmiła jego wszechstronność i zawarte w tekstach przesłanie - ową zaszczepioną przez Manès'a Sperbera „ludzką orientację"33.

Trudność w recepcji Jürgena Fuchsa polega również na tym, iż pisarz ten za wszelką cenę chciał pokazać opinii publicznej, jakie jest prawdziwe oblicze wschodnioniemieckiej jedności, równości i braterstwa, jak wygląda rzeczywistość życia w "drugiej niemieckiej dyktaturze”, gdzie na porządku dziennym było łamanie fundamentalnych praw człowieka. Autor ten był jedną z niewielu osób, które dysponowały tzw. „podwójnym filmem (Heinz Brandt). Znał drugą stronę [...]", wiedział, o czym mówi, kiedy konfrontował czytelników "z historycznym brakiem perspektyw socjalistycznego porząd $\mathrm{ku}^{\prime \prime 34}$, co z wielu względów nie odpowiadało wyobrażeniom nie tylko władz NRD, lecz także pewnych kręgów w RFN, w szczególności tamtejszej lewicy, która upatrywała w nim wichrzyciela burzącego przyszłość stosunków na linii Bonn-Berlin Wschodni. Ponadto biorąc pod uwagę fakt, iż jego proza wypełniona była cytatami obrazującymi nomenklaturę Stasi, ów język „,sprawców”, urzędowy styl i składnię, trudne w zrozumieniu dyrektywy i skróty, przytaczane wyłącznie w celu uzmysłowienia, co może się kryć „za preambułami, frazami i wzniosłymi słowami"35, to wtedy lepiej zrozumie się powody momentami ostrej krytyki autora, przez złośliwych uważanego „za pierwszego, odnoszącego sukcesy przedstawiciela tzw. niemieckiej literatury poszkodowanych" ${ }^{\prime 36}$, bądź jednego $\mathrm{z}$ „mało zdolnych literatów, zajmujących się rozliczeniem z historią SED i Stasi w celu zdobycia uznania, z którym nie spotkali się w odniesieniu do ich dzieła" ${ }^{\prime \prime 2}$.

Trzeba zaznaczyć, iż owych negatywnych opinii na szczęście nie podzielają wszyscy, tym bardziej, że wiele zarzutów kierowanych pod adresem pisarza to reakcja na publikację wspomnianej już pozycji „Magdalena”, która nie dość, że została przez wiele osób niewłaściwie zinterpretowana, to była powodem momentami ostrej krytyki jej autora. Lecz nie należy

${ }^{33}$ Por. m.in. Fuchs J., Einer hat mitgedacht, Ermutigung als Widerstand. Manès Sperber Wirkung im realen Stalinismus, „Neue Gesellschaft. Frankfurter Hefte”, Heft 11, 1990, s. 1031-1041; Fuchs J., Die Schnürsenkel von Torgau oder Der Verlust der humanen Orientierung, [w:] Hardtwig W., Winkler H.A. (Hg.), Deutsche Entfremdung. Zum Befinden in Ost und West, München 1994, s. 31-67; Fuchs J., Der Kampf um die Erinnerung. Verantwortung und Lüge. Über Manès Sperber, [w:] Kratschmer E., Literatur + Diktatur, Jena 1997, s. 63-74.

${ }^{34}$ Scheer U., Jürgen Fuchs..., op. cit., s. 211 (tłum. własne).

${ }^{35}$ Fuchs J./Hieke G., Dummgeschult..., op. cit., s. 5 (tłum. własne).

${ }^{36}$ Scheer U., Jürgen Fuchs..., op. cit., s. 211. Por. Killy W., Literaturlexikon, Berlin 2000, Bd. 4, S. 55.

37 Hoffmann F., Sprache - Dichtung - Leben, „Deutschland Archiv. Zeitschrift für das vereinigte Deutschland", Heft 3/2012, s. 562 (tłum. własne). 
zapominać, że ostatnia, pisana w wyścigu z nieuleczalną chorobą powieść nie powinna przyćmić pozostałego dorobku Jürgena Fuchsa, który dzięki swojej twórczości zasłynął jako „wybitny moralista, polityczno-historyczny nauczyciel, zadziorny bojownik" oraz „świadomy języka poeta”. Wielu odbiorcom w Niemczech brakuje dziś jego osoby, tego jakże wyraźnego profilu i prostolinijności, nic zatem dziwnego, że jego teksty zalicza się częstokroć w poczet tych „[...] ważnych dla przyszłości, nie tylko jako historyczne dokumenty, lecz także jako artystyczne modele konfrontacji z dyktaturą" ${ }^{\prime \prime 3}$. Dla szerokiego grona odbiorców Fuchs wciąż pozostaje twórcą „nowego typu tekstu: literacko-politycznego protokołu” ${ }^{\prime 39} \mathrm{i}$ „najważniejszym autorem nowej wschodnioniemieckiej literatury faktu"40, porównywanym z legendą tzw. dziennikarstwa „uczestniczącego" - Günterem Wallraffem ${ }^{41}$.

Mówiąc o recepcji i wizerunku pisarza nie sposób nie odnieść się też do zarzutu, z jakim można się spotkać podczas lektury recenzji i omówień dzieł Fuchsa, którego atakowano za uprawianie tzw. „litèrature engagèe" - literatury zaangażowanej politycznie, tendencyjnej, jedynie odtwarzającej rzeczywistość i rzekomo nie spełniającej literackich kryteriów. Wprawdzie teksty pisarza odnoszą się do polityki i wielokrotnie mają formę dokumentu, jednakże nie można potraktować ich jedynie jako publicystycznego sprawozdania, tym bardziej, że to właśnie „struktura tekstów (Fuchsa - przyp. E.K.), ich wielowarstwowość nadaje im charakter literacki. Istnieje (w nich - przyp. E.K.) wiele płaszczyzn. Odnajdujemy tam mieszankę strumieni świadomości ${ }^{42}$, wspomnień i refleksji na wielu poziomach, jak również opis i różnorodne formy cytowania $[\ldots]^{\prime \prime 33}$. Tak

\footnotetext{
${ }^{38}$ Ibidem, s. 563 (tłum. własne).

39 Schmitt H.-J. (Hg.), Hansers Sozialgeschichte der deutschen Literatur, Band 11: Die Literatur der DDR, s. 322 (tłum. własne).

${ }^{40}$ Scheer U., Jürgen Fuchs..., op. cit., s. 211 (tłum. własne).

${ }^{41}$ Warto zaznaczyć, iż Jürgen Fuchs w latach swojej młodości czerpał inspiracje z reportaży Güntera Wallraffa, szczególnie tych opisujących jego służbę w armii RFN. W wywiadzie Wallraffa z Fuchsem (zatytułowanym „Beschreiben, was ist, was war") czytamy: „Ich wollte Klartext schreiben, nicht nur Gedichte im lyrischen Ton von Bobrowski. In dieser Phase spieltest du mit deinen Reportagen, die ich in der Armee gelesen habe, eine wichtige Rolle. [...] Irgendwie hat es mich jedenfalls erreicht. Vielleicht auch als Westbuch. [...] Und das brachte mich dazu, bei Prosalesungen in der Kirche, [...] die Frage zu stellen: Ermittelte Wallraff bei der Bundeswehr oder bei der NVA?" Por. Wallraff G., Mein Tagebuch aus der Bundeswehr, Köln 1992, s. 125.

42 Pojęcie "strumień świadomości” (niem. Bewusstseinströme) to termin literacki uformowany na przełomie XIX/XX w. (zapożyczony z języka angielskiego: „stream of consciousness"), oznaczający technikę narracji, przypominającą współczesną formę monologu wewnętrznego, w której szczególnie akcentowane są refleksje, wspomnienia, uczucia i spostrzeżenia.
}

${ }^{43}$ Fix U., Widerständige Sprache..., op. cit., s. 89 (tłum. własne). 
oto profesor Ulla Fix charakteryzuje utwory Jürgena Fuchsa, zaznaczając przy tym (podobnie jak inni literaturoznawcy: Joachim-Rüdiger Groth czy Wolfgang Emmerich), że nie można podważyć literackości jego dzieł, chociażby że względu na fakt, iż widoczna jest w nich intertekstualność, polifonia czy kolaż, stosowane są m.in. metafory, aluzje, uogólnienia oraz zagęszczenia ${ }^{44}$.

W tym kontekście trzeba przyznać, iż powyższe argumenty nie są w stanie po dziś dzień przekonać o tym, że pewna część twórczości Fuchsa (przede wszystkim jego powieści) to wartościowa literatura w pełnym tego słowa znaczeniu. Niestety, nie widzą, lub nie chcą zrozumieć tego jego liczni przeciwnicy, dopatrujący się $\mathrm{w}$ tekstach pisarza wyłącznie politycznej postawy i maniakalnego poszukiwania wyrażanej „wysokim tonem" prawdy ${ }^{45}$. Na szczęście nie sądzą tak wszyscy, po stronie niedocenianego literata staje m.in. Herta Müller - osobowość, której opinia w pewien sposób zachęca do zastanowienia się i spojrzenia na dorobek Jürgena Fuchsa w innym, bardziej pozytywnym świetle. Stwierdza ona, że „Wielu ludzi musi się na niego powoływać. Przez jednych, w imieniu których przemawia (do których się zaliczam), jest on podziwiany. Przez innych, którzy nie mogą ścierpieć jego prawdy, jest on nienawidzony oraz oczerniany. [...] Dla obu stron Jürgen Fuchs stał się symbolem, obie strony często mówią o nim jako osobie politycznej, lecz rzadko o jakości jego literatury. [...] Jego teksty nie pouczają, lecz otwierają oczy. Spokojnie można powiedzieć, że poprzez swoją autentyczność wychowują. Kto chce się dowiedzieć, jak siła i bezsilność wyglądają z zewnątrz i od środka, będzie musiał je przeczytać" ${ }^{\prime 46}$.

Podsumowując: Jürgen Fuchs - swego czasu jeden z najważniejszych autorów urodzonych w NRD żyjących na przymusowej emigracji - to postać polaryzująca swoją postawą, nietuzinkowa, w pewnym sensie nierozumiana, niedoceniona oraz nieodkryta. Jego aktualna recepcja i wizerunek w RFN są tego najlepszym przykładem. Oprócz starań rodziny i przyjaciół jedynie z rzadka można wskazać na inicjatywy ${ }^{47}$, które uho-

${ }^{44}$ Por. tamże, s. 90-95.

45 Walther J., Wortkaskaden wie Gottesurteile, „Der Spiegel”, nr 14/1998, s. 88.

${ }^{46}$ MüllerH., Der Blick derkleinen Bahnstationen. Über dieliterarisch-dokumentarische Wirkung von Jürgen Fuchs, „Horch und Guck”, Heft 64 (02/2009), s. 65 (tłum. własne).

${ }^{47}$ Od momentu śmierci pisarza w dn. 9 maja 1999 roku pamięć o Jürgenie Fuchsie pielęgnowana jest w RFN na różne sposoby - do najważniejszych inicjatyw honorujących zmarłego autora zaliczyć należy: sympozjum „Einmischung in eigene Angelegenheiten”, zorganizowane przez Geschichtswerkstatt Jena e.V. i Collegium Europaeum Jenense (Jena, 8-10.12.2000); seminarium literackie „Jürgen Fuchs zum 60. - ein Leben zwischen Anspruch und Wirklichkeit", przygotowane przez: Geschichtswerkstatt Jena e.V., Collegium Europaeum Jenense oraz Landesbeauftager des Freistaates Thüringen für die Unterlagen des Staatssicherheitsdienstes der ehemaligen DDR (Jena 26-27.11.2010); wydanie 
norowałyby i ukazały we właściwym świetle dokonania tego wyjątkowego pisarza ${ }^{48}$. W trzynaście lat po jego śmierci o jego osobie przypominają trzy miejsca w byłej NRD - ulica w Erfurcie, plac w Berlinie oraz biblioteka w rodzinnym Reichenbach, lecz to chyba zbyt mało, by ocalić jego osobę i dorobek przed zapomnieniem. W tym celu należałoby nie tylko zadbać o wznowienie jego dostępnych w dniu dzisiejszym prawie wyłącznie antykwarycznie książek, lecz przede wszystkim odpowiednio zinterpretować jego twórczość i podjać próbę wyzwolenia go z piętna autora politycznego. Owo literackie „uwolnienie” Jürgena Fuchsa jest możliwe, chociażby poprzez dokładną analizę jego twórczości, co być może przyczyniłoby się do umieszczenia jego nazwiska w większej ilości leksykonów pisarzy niemieckich ${ }^{49}$, uwzględnienia jego liryki i prozy w kanonie lektur obowiązkowych ${ }^{50}$, a nade wszystko spopularyzowania jego dzieła, którego przesłanie wydaje się być ponadczasowe. Swoistym potwierdzeniem są słowa Güntera Kunerta, który niejako w zastępstwie zmarłego

dwóch książek mówionych (audiobooków): Liebermann D. (Hg.), Das Ende einer Feigheit. Mit einer Einführung von Herta Müller und einem Lied von Wolf Biermann, Hörbuch, 2 CDs, Hamburg 2011; Liebermann D. (Hg.), Landschaften der Lüge. Gespräche mit Jürgen Fuchs. Mit einem Vorwort von Roland Jahn, Hörbuch, 2 CDs, Hamburg 2013; obchody 10. rocznicy śmierci pisarza, zorganizowane przez Izbę Deputowanych w Berlinie (15.06.2009). Pokłosiem w/w uroczystości były następujące publikacje: „Gerbergasse 18”, Sonderausgabe zum Fuchs-Symposium „Einmischung in eigene Angelegenheiten” (hrsg. von Geschichtswerkstatt Jena e.V), Jena 2001; Jürgen Fuchs - Dichter, Psychologe, Bürgerrechtler (hrsg. vom Präsidenten des Abgeordnetenhauses von Berlin), Berlin 2010; Hermann M./Pietzsch H. (Hg.), DDR-Literatur zwischen Anpassung und Widerspruch, Jena 2011.

${ }^{48}$ Za swoje dokonania literackie Jürgen Fuchs otrzymał następujące nagrody i wyróżnienia: Internationaler Pressepreis (1977), Marburger Literaturpreis (1982), Thomas-Dehler-Preis (1987, wraz z S. Andersonem), Deutscher Kritikerpreis für Literatur (1988), Hans-Sahl-Preis (1999/posthum).

${ }^{49} \mathrm{~W}$ ważniejszych niemieckojęzycznych leksykonach oraz słownikach pisarzy brak jest częstokroć wzmianki o Jürgenie Fuchsie, jak np. w: Metzler Autoren Lexikon: Deutschsprachige Dichter und Schriftsteller vom Mittelalter bis zur Gegenwart (Stuttgart 1986), Reclams Romanlexikon, Bd. 3 - 20. Jahrhundert (Stuttgart 1999), Harenbergs Lexikon der Weltliteratur. Autoren, Werke, Begriffe (Dortmund 1989). Autor niniejszego artykułu odnalazł noty o pisarzu m.in. w: Kindlers Neues Literatur-Lexikon, Bd. 21-Supplement A-K (München 1998); Hansers Sozialgeschichte der deutschen Literatur, Bd. 11 - Die Literatur der DDR (München 1993) oraz Kritisches Lexikon zur deutschsprachigen Gegenwartsliteratur (München 2012).

${ }^{50}$ W 2001 roku ministerstwo kultury kraju związkowego Turyngia zaliczyło tomik wierszy J. Fuchsa pt. „Schriftprobe” (wydany po śmierci pisarza przez jego mentora z czasów młodości - prof. Edwina Kratschmera) do lektur zalecanych dla klas 9-12. Niestety jest to jedyna pozycja tego autora widniejąca w kanonie lektur w RFN. „Schrifprobe” to cykl 27 wierszy, napisanych wiosną 1972 roku, które ze względu na swoją wymowę i grożące sankcje nie zostały wydrukowane w NRD w całości, jedynie 12 z nich przedrukowano w antologii Offene Fenster. Schülergedichte, Bd. 4, Berlin 1973 (red. E. und M. Kratschmer, H. Würtz). Por. Fuchs J., Schriftprobe. Frühe Gedichte (vorgelegt von E. Kratschmer), Weimar 2000. 
przedwcześnie ${ }^{51}$ pisarza stwierdza: „Jeżeli chcemy wiedzieć jak było, potrzebujemy świadectwo literackie poszkodowanych. Dopiero wtedy możemy, jeżeli tego chcemy, wczuć się mentalnie w ich czasy i otoczenie. Bez książki, bez poezji, która opowiada nam o losach, bez poezji, która nasze i poety odczucia zjednuje, posiadalibyśmy tylko stosy akt, z których poznalibyśmy wprawdzie fakty, ale nigdy stan duszy tych, którzy z powodu prawdy musieli cierpieć' ${ }^{\prime \prime 2}$.

\section{Zusammenfassung}

1978 hat Václav Havel seinen wichtigsten politischen Text vor der Wende verfasst und ihn mit folgendem Titel versehen: „Versuch, in der Wahrheit zu leben“ - diese schlichten Worte hat sich Jürgen Fuchs (1950-1999) nicht nur tief zu Herzen genommen sondern auch wirksam in die Tat umgesetzt. Der in die DDR hineingeborene Schriftsteller hat zeit seines Lebens mit der Feder unerbittlich gegen den "demokratischen“ Unrechtsstaat gekämpft, seine Schwächen entblößt, Kritik an der dort vorherrschenden Ordnung geübt, politischsoziale Tabuthemen angeschnitten, wofür er u.a. mit Auftritts- und Publikationsverbot belegt, kurz vor dem Studienabschluss exmatrikuliert, später verhaftet, neun Monate lang im MfS-Untersuchungsgefängnis Hohenschönhausen verhört, 1976 erpresserisch aus der Staatsbürgerschaft der DDR entlassen und in den Westen abgeschoben wurde. Somit war der zum Staatsfeind Nr. 1 abgestempelte Autor gezwungen, sein künstlerisches Glück in der neuen, bundesdeutschen Realität zu suchen.

Sein gesamtes literarisches Werk (Romane, prosaische Schriften, Gedichtbände, Theaterstücke, Essays) ist im Druck im West- und wiedervereinigten Deutschland erschienen. Jürgen Fuchs hat sich als politisierter Schriftsteller, kritischer Publizist, engagierter Bürgerund Menschenrechtler lebenslag eingemischt, das Schweigen gebrochen, gegen die Macht und Gewalt geschrieben, seine Stimme gegen die Amnesie, Verbrechen des SED-Staates, Täter sowie Zuträger des Systems erhoben und demnach zur Debatte herausgefordert. Damit ist er häufig in den Fokus der öffentlichen Kritik gerückt.

Im 21. Jahrhundert hat er für seine kompromisslose, jedoch oft falsch interpretierte Attitüde zu büßen. Im öffentlichen Bewusstsein ist er zwar präsent, doch leider vor-

${ }^{51}$ Jürgen Fuchs zmarł w wieku 48 lat na białaczkę, jednakże jego choroba - jak twierdził sam pisarz - nie rozwinęła się przypadkowo, lecz wywołana została poprzez naświetlanie promieniami gamma podczas dziewięciomiesięcznego pobytu w areszcie Stasi., Mimo wdrożonego śledztwa i badań nie udało się potwierdzić domniemań autora, jego rodziny i wielu osób z kręgu przyjaciół, tym bardziej, że w podobnych okolicznościach umarli także inni dysydenci, m.in. R. Bahro czy G. Pannach. Por. Corino K., "Hohes Verschleierungspotential”. Wurden Dissidenten von der DDR radioaktiv bestrahlt?, "Neue Züricher Zeitung", 16.06.1999; Schreiber J., Die Geschichte eines Verdachtes, „"Der Tagesspiegel”, 21.06.1999; Rietzschel T., Der Verdacht, FAZ”, 27.05.1999; Schneider J., Eine tödliche Dosis Angst, "Süddeutsche Zeitung”, 29.05.1999; Wensierski P., In Kopfhöhe ausgerichtet, „Der Spiegel”, nr 20/1999.

${ }^{52}$ www.exilarchiv.de/Joomla/index.php?option=com_content\&task=view\&id=408\&lang =polish (18.11.2012). 
wiegend als Oppositioneller, deutlich seltener als Schriftsteller, was selbstverständlich seinen aktuellen Bekanntschaftsgrad in der Literaturwissenschaft sowie germanistischen Forschung negativ beeinflusst. Aus diesem Grunde wird mit diesem Beitrag der Versuch unternommen, Jürgen Fuchs als einen bedeutenden Autor der Gegenwartsliteratur darzustellen, auf die Mittel seines künstlerischen Widerspruchs aufmerksam zu machen sowie auf die Rezeption und Funktion seiner Werke hinzuweisen, die heutzutage verbannt und verkannt zu sein scheinen. 